Jurnal IImiah KONTEKSTUAL

Volume 2, No. 2, Februari 2021, p. 9-16

\title{
STRATEGI SEKOLAH DASAR DALAM MENUMBUHKAN JIWA KEWIRAUSAHAAN PESERTA DIDIK
}

\author{
STRATEGIES FOR FOSTERING ENTREPRENEURSHIP VALUE ON \\ STUDENTS IN ELEMENTARY SCHOOL
}

\author{
Jauharil Maknuni \\ Pascasarjana Manajemen Pendidikan, Universitas Negeri Yogyakarta, Indonesia. \\ e-mail: jauharilmaknuni.2017@student.uny.ac.id
}

\begin{abstract}
ABSTRAK
Era globalisasi adalah kebebasan berusaha yang didorong dengan persaingan bebas yang tidak terbatas, sehingga setiap manusia dituntut lebih kreatif dan inovatif dalam berbagai bidang. Oleh sebab itu, untuk menghadapi persaingan ini, sekolah khususnya sekolah dasar perlu membekali peserta didik menjadi jiwa wirausaha. Penelitian ini bertujuan untuk mengetahui strategi sekolah dalam menumbuhkan jiwa kewirausahaan peserta didik. metode penelitianya kualitatif deskriptif, dalam mengumpulkan data penelitian ini mengunakan wawancara, dokumentasi dan observasi, dari hasil penelitan maka ditemukan beberapa strategi sekolah dalam menumbuhkan jiwa kewirausahaan peserta didik, yang terutama pada saat perencanaan dirumuskan didalam rapat sekolah setiap awal tahun ajaran. Penyusunan program dihadiri oleh ketua yayasan, komite, guru, staff dan orangtua peserta didik. program-proram ialah niaga santri, entrepreneur zone, culinary corner, pengusaha berbagi inspirasi dan berkebun. Ini bertujuan untuk agar peserta didik tertanam jiwa, karakter tanggung jawab, dan kepemimpinan. Pelaksanaan dilakukan pada peoses belajar mengajar, ektrakulikuler, dan mata pelejaran kewirausahaan, penelitian ini dapat memberi informasi kepada sekolah-sekolah lain dalam menerapkan dan menumbuhkan jiwa kewirausahaan peserta didik.
\end{abstract}

Kata kunci: Strategi Sekolah, Kewirausahaan

\begin{abstract}
Globalization era is a freedom in action encouraged by unlimited free competition thus, each person is demanded to be more creative and innovative in all aspects. Therefore, for schools in facing this competition, especially elementary schools, need to nurture entrepreneurship value on their students. We conducted this study to understand the strategies implemented by school in fostering entrepreneurship value on students. Descriptive qualitative research method was conducted in data collection from interview, documentation, and observation. We found several strategies implemented by school in fostering entrepreneurship value on its students, especially in plans formulated in school meeting on each beginning study year. The meeting is attended by chairman of foundation, board of committee, teachers, staffs, and students' parents. Therefore, several programs as follows are carrying out: student commerce, entrepreneur zone, culinary corner, inspiration sharing and farming. These programs are carrying out to foster responsibility and leadership value on students. The implementation of these programs is carried out in learning process, extracurricular and entrepreneurship subject. This study can provide information to other schools in fostering and implementing entrepreneurship value on students.
\end{abstract}

Keywords: School Strategy, Entrepreneurship 


\section{PENDAHULUAN}

Globalisasi membuat batas dalam suatu wilayah menjadi kabur dan memicu kebebasan berusaha dengan persaingan bebas. Hal ini menjadi tantangan tersendiri bagi bangsa Indonesia, khususnya dalam pembangunan ekonomi. Pembangunan ekonomi yang tepat tentu akan memberikan kesejahteraan ekonomi suatu bangsa. Masalah yang kerap dihadapi bangsa Indonesia dalam hal ini adalah semakin bertambahnya sumber daya manusia yang tidak diimbangi dengan luasnya lapangan pekerjaan. Hal ini tentu berdampak pada banyaknya pengangguran. Oleh sebab itu. peningkatan kualitas sumber daya manusia harus dilakukan secara terencana, terarah, intensif, efektif dan efisien dalam proses pembangunan.

Wiraswasta adalah langkah yang dapat ditempuh agar sumber daya manusia dengan lapangan pekerjaan dapat berimbang. Modal utama seorang wiraswasta adalah ketekunan yang dilandasi sikap optimis, kreatif dan melakukan usaha sebagai pendiri pertama disertai keberanian menanggung resiko [1]. Oleh sebab itu, pemerintah ikut merespon dengan membuat kebijakan untuk meningkat jiwa kewirausahaan yang diterapkan di sekolah-sekolah, khususnya Sekolah Dasar. Hal ini dilakukan dengan harapan peserta didik mempunyai jiwa kewirausahaan dalam diri mereka.

Perencanaan program untuk dapat meningkatkan jiwa kewirausahaan di Sekolah Dasar perlu dipersiapkan dengan matang. Hal ini karena perencanaan program merupakan pedoman pelaksanaan kegiatan, sehingga segala sesuatunya harus dipersiapkan agar membuahkan hasil yang sesuai dengan harapan [2]. Selanjutnya, sekolah memiliki peran yang sangat penting dalam mengembangkan kewiraussahaan peserta didik. Sekolah juga harus memberikan kenyamanan dalam proses belajar mengajar, sehingga dapat mencapai program yang telah di rencanakan.

Merujuk pada penelitian yang sebelumnya telah dilakukan, bahwa upaya sekolah dalam mengembangkan jiwa wirausaha peserta didik yaitu dengan adanya kegiatan intrakurikuler yang terdapat dalam kurikulum yang diterapkan oleh sekolah seperti pelajaran prakarya, kewirausahaan, dan mata pelajaran produktif lainnya [3]. Penelitian lain juga menguraikan kendala yang dihadapi sekolah dalam mengembangkan program yang dapat meningkatkan jiwa kewirausahaan, diantaranya penyusunan perangkat pembelajaran yang belum sesuai dan program kelas belum berjalan optimal [4].

Lebih lanjut, sekolah juga berperan dalam pembentukan keterampilan wirausaha peserta didik. Hal ini dapat dilakukan oleh sekolah melalui kegiatan sekolah yang mendukung peserta didik memperoleh pengetahuan dan keterampilan, mengembangkan karakter interpreneur [5]. Pemilihan model pembelajaran juga harus dilakukan secara tepat, agar pembelajaran menjadi lebih efektif, khususnya dalam menumbuhkan jiwa kewirausahaan peserta didik [6]. Jiwa kewirausahaan perlu ditumbuhkan sejak dini dalam diri peserta didik sejak dini agar saat terjun ke masyarakat telah siap berwirausaha. Pemerintah dalam hal ini juga bertanggungjawab menumbuhkan jiwa kewirausahaan peserta didik melalui pendidikan kewirausahaan. Pendidikan kewirausahaan merupakan alternatif jalan keluar untuk mengurangi tingkat pengangguran.

Program kelas wirausaha belum mencapai optimal, disebabkan kurang adanya kejelasan pelaksanaan dan pemahaman kurikulum kelas wirausaha sehingga pelaksanaannya perlu di evaluasi, walaupun dari skill yang dicapai peserta didik cukup baik [4]. Sekolah Dasar Khalifah Yogyakarta adalah sekolah dasar yang telah memiliki program untuk menumbuhkan jiwa kewirausahaan peserta didik. Oleh sebab itu, penelitian ini bertujuan untuk meneliti strategi sekolah dalam menanamkan jiwa kewirausahaan peserta didik di Sekolah Dasar khilafah Yogyakarta, baik secara perencanaan, pelaksaan, dan evaluasi penerapan kebijakan tersebut.

\section{METODE PENELITIAN}

Penelitian ini adalah penelitian lapangan yang menggunakan pendekatan studi kasus. Fokus yang diteliti oleh peneliti adalah strategi sekolah dasar dalam menumbuhkan jiwa kewirausahaan peserta didik. Penelitian ini dilakukan di SD khalifah Yogyakarta. Data dalam penelitian kualitatif 
terdapat 2 macam, yaitu data primer dan data sekunder. Data primer dalam penelitian ini diperoleh melalui observasi mendalam dan wawancara. Selanjutnya, untuk memperkuat data primer, data sekunder diperoleh dari berbagai buku dan jurnal yang relevan dengan penelitian. Teknik sampling yang digunakan adalah purposive sampling. Purposive sampling yaitu teknik pengambilan informan dengan pertimbangan tertentu [7].

Penelitian ini menggunakan beberapa teknik pengumpulan data, antara lain wawancara, observasi, dan dokumentasi. Pengujian keabsahan data yang telah terkumpul, menggunakan teknik triangulasi sumber, yaitu dipelajari dan ditelaah secara mendalam untuk kemudian dilakukan reduksi data, koding dan penarikan kesimpulan. Analisis data menggunakan Model Miles and Huberman, adapun komponen dalam analisis data tersaji dalam Gambar 1, sebagai berikut.

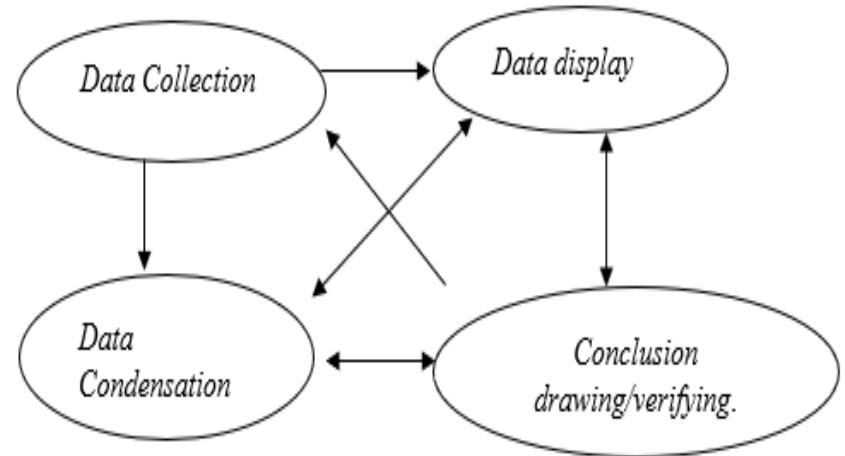

Gambar 1. Komponen dalam analisis data (interactive model) [8]

\section{HASIL DAN PEMBAHASAN}

\section{Hasil Penelitian}

Perencanaan Sekolah Dasar dalam Menumbuhkan Jiwa Kewirausahaan Peserta didik

Pendidikan kewirausahaan merupakan pendidikan kecakapan hidup bagi peserta didik yang berguna sebagai bekal untuk menghadapi berbagai permasalahan dan persaingan yang semakin kompetitif, canggih dan kreatif. Dengan adanya mata pelajaran kewirausahan sekolah akan menumbuhkan nilai-nilai kewirausaha dalam diri peserta didik dengan berbagai kegiatan. Seperti yang di ungkapkan oleh WK bahwa "kita ingin peserta didik mandiri, berani dan kratif di masa depan, apalagi dunia saat ini sangat canggih dan bersaing". Guru berharap peserta didik mempunyai bekal menjadi pengusaha dan mampu menciptakan lapangan pekerjaan yang bisa berguna untuk dirinya dan orang banyak.

Tentu tidak terlepas dari perencanaan yang dilakukan sekolah, seperti yang di ungkap oleh guru WP "Program pendidikan kewirausahaan di SD Khalifah ialah niaga santri, entrepreneur zone, culinary corner, pengusaha berbagi inspirasi, dan lain-lain. Nantinya akan dilaksanakan secara rutin oleh seluruh warga sekolah" dan juga dijelaskan oleh WK "ada niaga santri, memasak bersama atau culinary corner, ada juga mata pelajaran entrepreneur zone, sama pengusaha berbagi inspirasi" dan juga di dukungan berbagai perencanaan program-program kegiatan sekolah seperti yang dikatakan oleh WP

"untuk perencanaan program pendidikan kewirausahaan akan dilaksanakan di dalam rapat tahunan, untuk merumuskan dan menentukan program apa saja yang akan dilaksanakan selama setahun" dan berikut yang diungkapkan oleh waka kurikulum "pada saat rapat perencanaan kita juga ikut mengundang orangtua peserta didik"

Pendidikan kewirausahaan perencanaan program di lakukan pada saat rapat tahun dan ikut melibatkan orang tua dalam proses tersebut, karena setiap program orangtua harus mengetahuinya agar semua program tersebut dapat berjalan dengan baik sesuai dengan target yang diharapkan. Pendidikan wirausahaan juga akan disesuaikan seperti yang di ungkapakn WP 
"kita mengacu pada kurikulum yang telah disepakati itu ada 5 nilai-nilai pokok Pendidikan kewirausahaan yang akan ditanamkan yang pertama itu kemandirian, kreatif, berani mengambil resiko, berorientasi pada tindakan dan leadership atau kepemimpinan. Namun kita juga menanamkan karakter-karakter yang lainnya sesuai dengan kurikulum 2013"

Dan berikut yang dijelaskan guru WK

"memastikan peserta didik terlibat aktif dalam berbagai kegiatan yang kita bagi jadi 3 kategori yaitu kegiatan pembelajaran di kelas, kegiatan ekstrakulikuler, kegiatan pengembangan diri. Tambah guru ibu ani nilai-nilai dasar kewirausahaan dengan cara kepala sekolah dan guru memastikan peserta didik ikut serta mengikuti seluruh kegitan sekolah. guru selalu membimbing dan memantau perkembangan masing-masing anak pada setiap harinya"

Dalam menyukseskan perencanaan program maka guru aktif telibat dalam setiap kegiatan, seperti kegiatan pembelajar, ekstrakulikuler dan guru harus siap membimbing dan mendampingi dan memantau perkembangan setiap hari.

\section{Pelaksanaan Sekolah Dasar dalam Menumbuhkan Jiwa Kewirausahaan Peserta didik}

Pelaksanaan pendidikan kewirausahaan yang dilakukan sekolah melalui seluruh mata pelajaran yang sudah ada di sekolah. Seperti yang di ungkap WK "Guru selalu menyisipkan muatan-muatan tentang entrepreneurship pada setiap proses pembelajaran dan mengaitkan dengan nilai-nilai kewirausahaan" dari penjelasan di atas guru selalu mengaitkan nilai-nilai kewirausahaan dalam setiap mata pelajaran dengan harapan dapat terbentuk karakter kewirausahaan. Seperti yang di ungkap WK:

"ada banyak metode pembelajaran yang digunakan, dan mengintruksikans semua guru agar menggunakan tehnik pembelajaran yang aktif dan menyenangkan dalam proses belajar mengajar. Seperti metode permainan, diskusi, praktik lapangan"

Dari penjelasan di atas maka guru harus menciptakan suasana belajar yang aktif dan kreatif. dan guru harus pintar memilih dan memilah metode yang cocok agar peserta didik semangat dalam proses belajar mengajar, dengan begitu akan mudah dalam menanam nilai-nilai kewirausahaan. Tidak hanya lewat mata pelajaran akan tetapi juga melalui kestrakulikuler karate seperti yang di ungkap WP "kegiatan ekstrakulikuler juga ditanamkan nilai-nilai kewirausahaan seperti kemandirian. kepemimpinan, kreatif dan berorientasi pada tindaka" dan tidak hanya ekstrakulikuler karate, robotik dan pramuka salah satu program yang tepat untuk menciptakan peserta didik lebih mandiri dan bertanggung jawab seperti juga yang diungkapkan WK

"Pada kegitan ekstrakulikuler juga ditanamkan nilai-nilai kewirausahaan misalnya kepemimpinan, kreatif dan berorientasi pada tindakan. Apalagi di pramuka ya, biasanya sudah lengkap untuk nilai-nilai karakter kewirausahaannya"

Ekstrakulikuler karate, robotik dan pramukan Program yang tepat untuk menumbuhkan dan mencetak jiwa wirausaha seperti akan lahir pada jiwa kepemimpinan, rasa tanggung jawab, kerjasama tim, saling menghargai dan saling tolong menolong antar peserta didik. Pelaksanaan pendidikan untuk menumbuhkan jiwa kewirausahaan ini juga seperti peserta didik ikut serta dalam kegiatan ektrakulikuler dan kegiatan pengembangan diri. Seperti yang di ungkapkan oleh WP

"Kegiatan pengembangan diri ada lumayang banyak, misalnya niaga santri yang setiap selasa dan jum'at pagi untuk menamkan jiwa berorientasi pada tindakan karena anak akan praktek langsung untuk berjulan di sekolah dan juga ada jiwa kreatif dan kemandirian nya"

Berikut yang dijelaskan oleh WK

"Kegiatan Culinary Corner ialah kegiatan memasak makanan bersama yang dilakukan oleh peserta didik di lingkungan sekolah yang dilaksanakan satu kali dalam dua bulan. seminggu 2 kali untuk kegiatan jual beli di sekolah dimana ada empat orang peserta didik yang ditugaskan untuk berjualan, kita ada program 
seperti peserta didik bergeliran setiap minggu membuat kue dirumah setelah itu mereka menjual di sekolah kepada teman-temannya maupun kepada teman kelas lain dan uang tersebut akan masuk ke kas kelas"

Uang yang di hasilkan akan di tabung ke kas kelas untuk membeli keperluan kelas dan sangat penting sekolah bekerja sama dengan orangtua dalam menyukseskan semua program sekolah. Seperti yang di ungkapkan WK "ada culinary corner kegiatan memasak bersama untuk menanamkan kemandiran, berorientasi pada tindakan dan berani mengambil resiko Memasak bersama, niaga santri sama mata pelajaran entrepreneur zone" culinary corner kegiatan pengembangan diri peserta didik untuk menananm nilai mengambil keputusan dan bertanggung jawab setiap resiko yang dihadapi.

Program berkebun salah program yang di gagas sekolah untuk menanam nilai-nilai kerja keras seperti yang di ungkap oleh WK "Kegaiatan berkebun atau bercocok tanam untuk karakter kerja keras pada peserta didik" Tidak hanya itu untuk meningkatkan semangat peserta didik dalam membangun jiwa wirausaha peserta didik sekolah juga mendatangkan pengusaha untuk berbagi inspirasi, seperti yang di ungkapkan WP "kita juga ada program pengusaha berbagi inspirasi, dimana nanti kita mengundang tokoh-tokoh pengusaha yang sudah sukses untuk memberikan motivasi kepada anak untuk melatih leadership" program ini salah satu program untuk memotivasi dan semangat peserta didik untuk terus berkarya.

Kalau pada kelas rendah biasanya materinya lebih ringan misalnya cara melipat pakaian, cara menyapu yang benar dan cerita kisah-kisah nabi Muhammad dalam berdagang. Kalau untuk kelas tingginya biasanya sudah dibebankan untuk membuat produk berupa karyakarya seni. Berikut yang di jelasakan WP"namun secara khusus sekolah membuat mata pelajaran khusus pada muatan lokal untuk wawasan muatan kewirausahaan pada mata pelajaran entrepreneur zone yang dilaksanakan setiap minggunya" sekolah membuat kebijakan khusus untuk peserta didik agar semua target yang di ingikan sekolah tercapai.

\section{Pembahasan}

Perencanaan Sekolah Dasar dalam Menumbuhkan Jiwa Kewirausahaan Peserta didik

Proses perencanaan sekolah dalam menumbuhkan jiwa kewirausahaan peserta didik dirumuskan didalam rapat sekolah setiap awal tahun ajaran baru dan sekolah mengagas beberapa porgramprogram untuk mencapai target dengan baik. Penyusununa program dihadiri oleh ketua yayasan, komite, guru, staff dan orangtua peserta didik. Peran Sekolah Sebagai Lembaga Pendidikan mempunyai peran untuk mengembangkan potensi manusiawi yang dimiliki anak-anak agar mampu menjalankan tugas-tugas kehidupan sebagai manusia [5]. Tugas kehidupan manusia baik secara individual maupun sebagai anggota masyarakat. Hal ini dilakukan dengan cara membentuk kepribadian anak-anak agar menjadi manusia dewasa yang mampu berdiri sendiri di dalam kebudayaan dan masyarakat sekitarnya. Program yang telah disepakati akan disahkan oleh semua pihak dan diterapkan pada kegiatan-kegiatan yang ada SD Khalifah Yogyakarta.

Program-program kegiatan tersebut diantaranya ialah niaga santri, entrepreneur zone, culinary corner, pengusaha berbagi inspirasi dan berkebun. Program-program tersebut, bertujuan untuk agar dalam diri peserta didik tertanam karakter tanggung jawab dan kepemimpinan. Hal ini karena generasi muda sangat memerlukan pengetahuan fungsional dan keterampilan agar dapat membangun karakter, sikap, dan visi yang selaras dengan kehidupan [9].

Semua ini bertujuan untuk menanam nilai jiwa kewirausahaan yaitu kemandirian, kreatif, kepemimpinan, dan bertanggung jawab setiap keputusan yang diambil Hal ini sejalan dengan pendapat [10]. Tahap pertama implementasi nilai-nilai kewirausahaan diambil lima nilai pokok yaitu mandiri, kreatif, bertanggung jawab, kepemimpinan, dan minat berusaha [11]. Oleh sebab itu, menumbuhkan minat bagi peserta didik sangat penting dilakukan untuk dapat memunculkan keinginan bekerja keras atau kemauan keras dengan adanya pemusatan perhatian untuk berusaha memenuhi kebutuhan. 


\section{Pelaksanaan Sekolah Dasar dalam Menumbuhkan Jiwa Kewirausahaan Peserta didik}

Metode sekolah dalam menanam jiwa kewirausahaan peserta didik dengan berbagai kegiatan di sekolah, seperti pada saat proses belajar mengajar guru tentu akan mengaitkan kepada kewirausahaan. Pada saat pelaksanaan pembelajaran di kelas, guru tidak perlu mengubah pokok bahasan yang sudah ada tetapi menggunakan materi pokok bahasan itu untuk mengembangkan nilai-nilai kewirausahaan [10]. Proses pembelajaran yang aktif dan menyenangkan diharapkan mampu membuat peserta didik lebih bersemangat dalam proses pembelajaran dan guru harus tahu metode yang cocok untuk mendampingi peserta didik. Oleh sebab itu, peran guru sangat diperlukan dalam membimbing, melatih, dan mendidik peserta didik.

Kegiatan ekstrakulikuler yang dilaksanakan di luar mata pelajaran di kelas, seperti pramuka, karate, robotik. Semua ini bertujuan agar peserta didik memailiki jiwa pemimpin, tolong menolong, menghargai dan mandiri. Sifat-sifat yang perlu di miliki oleh calon wirausaha yaitu harus percaya diri, berorientasi pada tugas dan hasil, pengambilan resiko, kepemimpinan dan berorientasi ke masa depan [1]. Selain itu, kegiatan pengembangan diri budaya sekolah ini sekolah betujuan Kegiatan pengembangan diri rutin dilaksanakan di SD Khalifah menyesuaikan dengan jadwal yang sudah ditentukan. Kegitan ini wajib diikuti oleh seluruh peserta didik dari kelas satu sampai kelas lima dan terkadang juga melibatkan banyak pihak seperti kepala sekolah, guru, staf pegawai, orang tua peserta didik dan pemateri dari luar sekolah yaitu seorang pengusaha.

Kegiatan lain untuk menumbuh jiwa wirausasahaan peserta didik dengan niaga santri dapat juga diistilahkan dengan market day atau hari pasar. Market day dapat dijadikan penanaman jiwa kewirausahaan kepada peserta didik [12]. Pendidikan kewirausahaan di SD Khalifah Yogyakarta dilakukan melalui muatan lokal dengan mata pelajaran khusus kewirausahaan yaitu mata pelajaran entrepreneur zone

Kegiatan pengusaha inspirasi ialah kegiatan menghadirkan pengusaha muslim sukses ke SD Khalifah Yogyakarta untuk memberikan motivasi kepada peserta didik yang dilaksanakan satu kali dalam dua bulan. Peserta didik diberikan motivasi kewirausahaan melalui metode ceramah games dan permainan yang menarik lainnya. Kegiatan Culinary Corner ialah kegiatan memasak makanan bersama yang dilakukan oleh peserta didik di lingkungan sekolah yang dilaksanakan satu kali dalam dua bulan. Kegiatan memasak merupakan bentuk dari pendekatan kontekstual yang diharapkan akan memberi lebih banyak pengalaman kepada peserta didik [13].

Disamping itu, kegiatan memasak juga dapat menumbuhkan motivasi yang berasal dari luar. Hal ini seperti riset yang sebelumnya pernah dilakukan, bahwa eorang wirausahawan wanita lebih pada motivasi ekstrinsik, yaitu peningkatan pendapatan yang bertujuan untuk memperoleh hidup yang nyaman [14]. Pendapatan yang diperolehnya akan menunjukkan jati diri seorang wanita sebagai pribadi yang mandiri, serta mampu memberikan keamanan finansial pada anggota keluarganya.

Pelajaran salah mata pelajaran yang di fokuskan untuk memberi pelejaran kepada peserta didik tentang kewirausahaan, seperti memasak. Kegiatan memasak ini biasanya ditemukan dalam pelajaran muatan lokal. Muatan lokal bertujuan bertujuan untuk mengembangkan potensi yang sesuai dengan keadaan dan kebutuhan daerah [15]. Pada prinsipnya, muatan lokal itu mengaplikasikan minat dan bakat peserta didik yang harus disesuaikan dengan kemampuan di sekolah masing-masing. Disamping itu, muatan lokal akan membuat peserta didik dekat dengan lingkungannya. Dengan demikian, kedekatan peserta didik dengan lingkungan, akan dapat menanamkan karakter yang baik pada diri peserta didik untuk lebih mencintai lingkungannya [16].

Jiwa kewirausahaan yaitu merupakan nyawa kehidupan dalam kewirausahaan yang pada dasarnya merupakan sikap dan perilaku kewirausahaan yang ditunjukkan melalui sifat, karakter dan watak seseorang yang memiliki kemauan dalam mewujudkan gagasan inovatif ke dalam dunia nyata secara kreatif [4]. Dengan demikian, pendidikan kewirausahaan dapat diintegrasikan melalui semua mata pelajaran, perubahan pembelajaran, ekstrakulikuler, pengembangan diri, kultur sekolah dan muatan lokal. 


\section{SIMPULAN}

Simpulan yang dapat ditulis dari hasil penelitian yang telah dilakukan yaitu, peran sekolah sangat besar dalam pembentukan keterampilan kewirausahaan peserta didik. Hal ini dapat dilihat dari berbagai macam program yang disusun bersama setiap awaal tahun ajaran baru. Program-program tersebut diantaranya niaga santri, entrepreneur zone, culinary corner, pengusaha berbagi inspirasi dan berkebun. Pelaksanaan dilakukan pada peoses belajar mengajar, ektrakulikuler, dan mata pelejaran kewirausahaan, penelitian ini dapat memberi informasi kepada sekolah-sekolah lain dalam menerapkan dan menumbuhkan jiwa kewirausahaan peserta didik.

Penumbuhan jiwa kewirausahaan peserta didik termasuk dalam proses belajar. Proses belajar tersebut tidak dapat dilakukan hanya dengan sekali program kegiatan. Program kewirausahaan hendaknya dapat dilakukan secara berkelanjutan, agar dapat mengembangkan jiwa kewirausahaan dalam diri peserta didik.

\section{DAFTAR PUSTAKA}

[1] B. Alma, Manajemen Pemasaran dan Pemasaran Jasa, 2018, Bandung, Alfabeta.

[2] A. Imron, Pembinaan Guru di Indonesia, 2007, Bandung, Remaja Rosdakarya.

[3] W. Dewanti, Upaya sekolah dalam mengembangkan jiwa wirausaha siswa (studi kasus pada siswa jurusan busana butik SMK N 6 Semarang), Skripsi, Fakultas Teknik, Universitas Negeri Semarang, 2015, Semarang.

[4] I. Nurbudiyani, "Manajemen pengembangan kewirausahaan (entrepreneurship) siswa SMKN 2 Palangkaraya," Pedagogik: Jurnal Pendidikan, vol. 10, no. 1, pp. 9-16, 2015, [Online].

Available:

http://journal.umpalangkaraya.ac.id/index.php/pedagogik/article/view/590

[5] W. R. Wahyuni and W. Hidayati, "Peran Sekolah dalam Membentuk Keterampilan Wirausaha Berbasis Tauhid di SD Entrepreneur Muslim Alif-A Piyungan Bantul Yogyakarta," MANAGERIA: Jurnal Manajemen Pendidikan Islam, vol. 2, no. 2, pp. 359377, 2017, [Online]. Available: http://ejournal.uinsuka.ac.id/tarbiyah/index.php/manageria/article/view/1624

[6] L. N. Aini, S. Muryaningsih, and D. Irawan, "Penerapan Model Missouri Mathematics Project Untuk Meningkatkan Hasil Belajar," Jurnal Ilmiah KONTEKSTUAL, vol. 2, no. 01, pp. 43-49, 2020, [Online]. Available: http://jurnal.umus.ac.id/index.php/kontekstual/article/view/248

[7] Sugiyono, Metode penelitian pendidikan, 2013, Bandung, Alfabeta.

[8] Matthew, B., Milles, A.M.H., Qualitative Data Analysis, 2014, California, Sage Publication.

[9] M. kumar Gautam \& S. Kumar Singh, Entrepreneurship Education: Concept, Characteristics and Implications for Teacher Education Entrepreneurship education, 2015, Ghana, University of Cape Coast.

[10] E. Mulyani, "Model pendidikan kewirausahaan di pendidikan dasar dan menengah," Jurnal Ekonomi dan Pendidikan, vol. 8, no. 1, pp. 1-18, 2011, [Online]. Available: https://journal.uny.ac.id/index.php/jep/article/view/705

[11] Q. Aini, Implementasi pendidikan kewirausahaan untuk menumbuhkan minat wirausaha siswa kelas X pada program enterpreneur di SMA Excellent Alyasini Pasuruan," Skripsi, Universitas Islam Negeri Maulana Malik Ibrahim, 2018, Malang.

[12] S. Muhammad, Mendidik \& Melatih Entrepreneur Muda /ARR, 2012, Yogyakarta, ArRuzz Media.

[13] J. Alimuddin and E. I. Yatmi, "Pendekatan kontekstual di sekolah alam lukulo Kebumen," 
Jurnal Ilmiah KONTEKSTUAL, vol. 1, no. 02, pp. 7-11, 2020, [Online]. Available: http://jurnal.umus.ac.id/index.php/kontekstual/article/view/156.

[14] D. Austhi, "Motivasi Berwirausaha dan Kesuksesan Berwirausaha pada Wirausahawan Wanita Anne Avanite," Agora, vol. 5, no. 1, 2017, [Online]. Available: http://publication.petra.ac.id/index.php/manajemen-bisnis/article/view/5327

[15] R. A. Fauqa, "Pengaruh Mata Pelajaran Muatan Lokal Kewirausahaan Terhadap Minat Berwirausaha Siswa," Skripsi, Universitas Tanjungpura, 2013, Sumatera Utara.

[16] S. Mardikarini, F. Hamdani, and C. Tyas, "Kegiatan wisata sampah untuk penanaman karakter cinta lingkungan pada siswa kelas IV SD," Jurnal Ilmiah KONTEKSTUAL, vol. 1 no. 01, pp. 58-65, 2020, [Online]. Available: http://jurnal.umus.ac.id/index.php/kontekstual/article/view/246 